\title{
Study on Innovation Personnel Training Mode in Automation Specialty
}

\author{
Shufen Liang, Hongwei Yue, Fangchen Yang, Yingying Fu, Chenfei Li, and Yihong He
}

\begin{abstract}
As guide to follow the development pace of higher education, the project education mode and innovative personnel trainning mode, this paper contributes to students' integrated development and adapt to society. As aim to these disadvantages in traditional automatical undergraduate education where there are around with paying attention on theory study more than innovative training, and the shortcomes about traditional teaching patterns. In terms of reforming talent training modes, studying and discussing the way of training automation professional engineering practice ability deeply on adjusting training program and innovating teaching modes and cooperation between school and enterprise, come up with the " $3+1$ " semester system and bring in the modern teaching techniques for innovative education and teaching patterns, establish effective training modes to promote innovation in training and teaching, so as to form a new mode for school enterprise cooperation training.
\end{abstract}

Index Terms-Engieering education, innovation and enterprise, " $3+1$ " personnel training mode.

\section{INTRODUCTION}

As the 13th Five-year planning of rail transit, heavy trucks and commercial vehicle industry, new materials, new energy (electricity) and equipment industry, education equipment industry, health industry, five big industry cluster development, has brought new opportunities to JiangMen's science and technology innovation, and with the "public entrepreneurship, peoples innovation" national strategy been put forward, "Zhu Xi Zhi Gu" is one of the innovation-driven strategy, including that education equipment basis is located, these have become a major platform to guide the development of creative industry. Adjacent to the " 'ZhuXi naokou' technology, measurement and automation instrument, electronic and computer technology, information processing, management and decision making, for students who can engage in system analysis, system design, system operation, science and technology development and research work of senior engineering and technical talents and set up an engineering professional. Facing the new situation, reforming the traditional personnel valley must be done", the highest institution of WuYi University, must contribute to "Zhu Xi Zhi Gu" by its advantages of talent and subjects, for

Manuscript received October April 15, 2018; revised December 5, 2018 This work was supported in part by the research on new model of automation professional engineering education (2015GXJK151), Information Full Life Cycle Cultivation of Talents Teaching Team(GDJX2017005), (GDJX2017002),Wuyi University- Jiangmen Southern Education Equipment Innovation Industry City Practice Base (GDJX2017006).

The authors are with WUYI University, China (e-mail: 13929048828@163.com,1085083863@qq.com,61265210@qq.com, 1970477466@qq.com, 513574233@qq.com, he_yihong@126.com). the talents cultivation, scientific research, making contribution to the development of creative industry. And automation as can cultivate in motion control, industrial process control, power electric training mode, establish innovative talents training mode, that is around the cultivation of students' innovative entrepreneurial practice ability, actively carry out the practice of educational policy [1]-[4].

\section{The Program of TAlent Training}

According to the situation in WuYi university, local economy and requirement of society, it should be that getting better training from projects, learning skills in usages of computer and jobs, handling enough innovation abilities in science, technology and organization management as the training goal and knowledge and talent structure of automation professional application-oriented talents.

So the training model of establishing the deep connotation of the subject, strong specialty, and the application-oriented creative talents based on engineering, is the key of the talent training. The training mode of " $3+1$ " is adopted to cultivate talents in common class and experimental class.

1) The scientific design on talent training scheme, the ordinary class actively promoted the " $3+1$ " talent training mode, the experimental class adopted the " $3+3+$ 1 " mode.

The " $3+1$ " mode is for the new situation in social development based on traditional four-term talent training mode. "3" means three years for studying theory, "1" is the fourth year of project training. In the current economic situation, students not only need to have a solid theoretical knowledge, but also need engineering practice and innovation ability.

However, the traditional four-terms cannot make students compact enough in theory study, as a result of lack of engineering practice training and innovation training. Therefore, the study of theoretical courses has been focused on the previous three years, and the fourth year has been applied to practice, internship, graduation design, innovation and other engineering practice sessions. In order to make students more compact in theoretical study time, the learning progress is more scientific and reasonable, and can concentrate time on engineering practice and innovation and entrepreneurship training. " $3+3+1$ " mode is the basis of the " $3+1$ " training mode and connect with the model of corporate cooperative education, the second " 3 " represent that adding three summer enterprise learning links. In order to train students to adapt to the training of engineering practice as soon as possible, training their Innovation and 
entrepreneurship in the process of enterprise learning. The experimental class is an important platform for universities and enterprises to jointly educate people.

2) Optimize curriculum management and strengthen professional knowledge learning. By combining the reality of professional disciplines and students, to a base class, practice class, professional class as the main content of the course system, to strengthen the conform to the law of education teaching and the characteristics of the development of entrepreneurship education innovation of innovation entrepreneurship training course content, appropriate to reduce theoretical class, increase the proportion of practice.

3) To build a scientific and effective innovative talent cultivation teaching mode.

Especially in constructing university-enterprise combination of personnel training mode, use cultivating students' practical ability as the core competence, the theory of basic knowledge and practical application ability to two or more things, establish a diversified talent assessment mechanism, incorporate the training quality of students' achievement assessment mechanism, analyses the students to master the solid basis of knowledge of professional degree and practical operation skills proficiency, as well as to the enterprise production specifications and compliance of security system, the formation of diverse talent assessment standard, comprehensive measure of students' comprehensive quality. The learning process of students is divided into two parts: school learning and enterprise training Schools can work together with businesses to develop teaching plans. Teachers can adopt the method of segmented teaching organization, select the production backbone of the enterprise production line and the senior professional technical staff as the students' practical training teacher [5].

4) Establish a regular return visit mechanism to improve the training plan.

5) We should strengthen and improve the education system and education form of innovation and entrepreneurship in applied universities.
Increase innovation entrepreneurship practice credit requirements, set up a credit accumulation and transfer system innovation and entrepreneurship and innovation practice in the training program related compulsory and elective credits, students will participate in the research, project experiment, discipline and the competition of science and technology, innovation, entrepreneurship training projects, published papers, and apply for a patent for quantitative evaluation and translated into corresponding credit [6].

\section{A. The Reform and Innovation of Curriculum System and Talent Training Program}

As an application-oriented undergraduate automation professional training mode is "thick base, wide aperture, focuses on practice, emphasis on application", its purpose is to cultivate engineering application innovation talents. As an automation professional course structure for applied undergraduate courses, it is necessary to explore "integrating new technologies and perfecting platform and modules" on the basis of local economy, highlighting the features of education. On the basis of the curriculum group, strengthening basic courses, streamlining the professional courses, ability training as the main line, the teaching module was closely related to the creation ability of engineering education goals needed, adaptability and practical ability, the practical based on systemic.

The courses offered in this major are divided into three major parts. Professional basic courses, professional basic courses and specialized courses are mutually supporting each other. The specific courses of each section are shown in Table I.

TABLE I: SPECIFIC COURSE SETTINGS FOR EACH SECTION

\begin{tabular}{|c|c|c|c|c|}
\hline & Course name & Term & period & credit \\
\hline \multirow{3}{*}{$\begin{array}{c}\text { Professional } \\
\text { basic platform } \\
\text { courses }\end{array}$} & Elementals of circuit analysis & 2 & 56 & 3.5 \\
\cline { 2 - 5 } & Low frequency electronic circuit & 3 & 48 & 3 \\
\cline { 2 - 5 } & Digital circuit and logic design & 4 & 48 & 3 \\
\hline \multirow{3}{*}{$\begin{array}{c}\text { Professional } \\
\text { basic courses }\end{array}$} & Signals and systems & 3 & 48 & 3 \\
\cline { 2 - 5 } & automatic control principle & 5 & 48 & 3 \\
\cline { 2 - 5 } & Sensors and electrical measurement technology & 5 & 32 & 2 \\
\cline { 2 - 5 } & power electronic technology & 5 & 38 & 3 \\
\cline { 2 - 5 } & Motor and drag Foundation & 6 & 48 & 3 \\
\cline { 2 - 5 } & Process control and instrument & 5 & 48 & 3 \\
\cline { 2 - 5 } $\begin{array}{c}\text { Professional } \\
\text { course }\end{array}$ & SCM Principles and Applications & 4 & 32 & 2 \\
\cline { 2 - 5 } & Motion Control Systems & 6 & 32 & 2 \\
\cline { 2 - 5 } & Computer control technology & 4 & 32 & 2 \\
\cline { 2 - 5 } & Electrical control and PLC & 3 & 16 & 2 \\
\cline { 2 - 5 } & Plant power supply & 32 & 2 \\
\hline
\end{tabular}

Using the " $3+1$ " education mode, we must optimize the professional curriculum, strengthen professional knowledge learning, adjusting and optimizing curriculum structure and content, make professional course more meet the needs of the development of society and the market, scientific configuration knowledge structure of innovative personnel training. The second is to strengthen the model management of innovative talent cultivation. Mainly system in my first three years of college study foundation courses, professional knowledge and innovation course is given priority to, the 
university last year according to the specialty curriculum overall practice, practice, practice, and achieve the combination of theory and practice, the accumulation of practice experience, improve the practice ability. To make students more compact in theory, at the same time, there are plenty of time for engineering practice and innovation and entrepreneurship training. The third is to establish the perfect innovation and entrepreneurship education system, the index quantification system, the assessment evaluation system. Innovation entrepreneurship class [7].

To cultivating talents for the target type having both ability and political integrity, to strengthen basic, attaches great importance to the innovation ability, outstanding characteristics for the principle, according to the intelligent manufacturing industry automation specialized talented person quality request, optimization automation professional talents cultivation practice courses and links, cognition practice, innovation training, comprehensive training of comprehensive training of information engineering, industrial automation, automatic control system, comprehensive training and other local intelligent manufacturing enterprises are closely linked, build progressive type of four years of engineering practice ability training and professional training course system. Improve students' comprehensive quality and innovation ability.

\section{THE IMPROVEMENT OF CURRICULUM CONSTRUCTION AND TEACHING METHOdS, WAys AND ASSESSMENT METHODS}

\section{A. Course Construction}

Focus on specialized core curriculum construction, especially the principle of automatic control, power electronic technology, sensor and electrical testing technology, modern control theory, the construction of the motor and basic courses. Build a curriculum group for "automation professional platform", establish a curriculum construction team, continuously deepen reform of the teaching system and teaching content, and continuously improve the teaching level, as shown in figure 1. Professional courses to finish jobs in accordance with the requirements of industry enterprise development and the actual work required to knowledge, ability, quality requirements, selection of teaching content, lay a foundation for the sustainable development of the students.

\section{B. The Method of Teaching}

Further deepening the reform of teaching mode, and gradually take properly with clear specific engineering alternation, task driven, project orientation, classroom and internship site integration, action-oriented teaching mode [8]. According to the content of the course and the characteristics of students, the teaching methods such as case analysis, group discussion, role playing and enlightening guidance should be flexibly used to improve students' learning interest and improve the effect of teaching and learning. Further update education concept, rational and effective scheduling, in-depth study of the modern teaching means in modern education technology and traditional teaching means reasonable combination, on the basis of optimizing the teaching process, improve the teaching quality and efficiency. The development of "automation platform" curriculum test library makes it easy to carry out the separation of "test teaching" and further improve the teaching quality of this course. Build "automation platform" course teaching website, outstanding quality class and high-quality goods, teaching materials, bibliography and excellent teaching video to open online, realize high quality teaching resources sharing of campus, give full play to the high quality class and the function of radiation and leading role of excellent courses. Strive to build the website into the "automation platform" course and the "automation platform curriculum resource library".

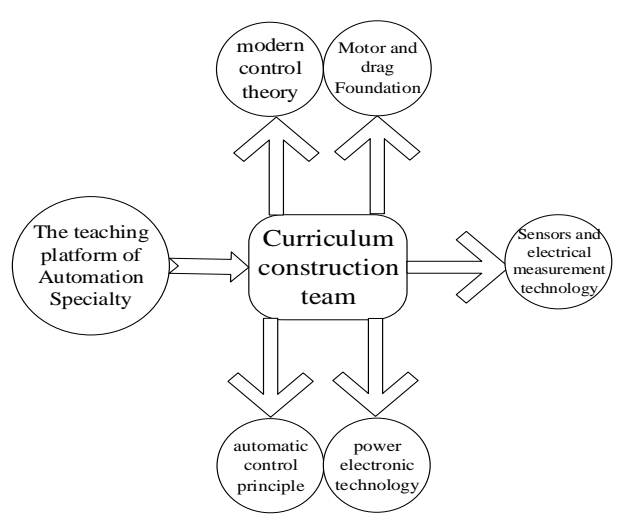

Fig. 1. Curriculum development.

On the basis of maintaining the traditional teaching advantage, the university teaching should be based on the change of the adult thinking mode, with The Times, with the bold innovation, and in the teaching of starting the micro-mode teaching. The micro-mode teaching mode is more free and flexible, and the teaching environment is more open and independent. In micro letter public platform, for example, the public letter provides a series of teaching support platform, can be used to preview before class, after class learning, curriculum evaluation, extra-curricular training, including personal information set function, social function, management function, data statistics, such as four categories.

\section{REFORM OF INNOVATIVE PRACTICAL TEACHING SYSTEM}

In the school enterprise cooperation, improve the innovative talents training plan, strengthen the practice base construction, establish a scientific and reasonable practice system, combining engineering education with local economic and industrial characteristics, realize engineering education innovation, improve students' engineering practice innovation ability. Regularly track social needs, meet the needs of enterprises for talents, fixed off-campus practice bases, and improve the guarantee system of practice links.

The construction of campus practice base can also be based on the cooperation of school enterprises, mutual benefit, common construction and common development. We will work together to improve the practice teaching system, and strengthen the construction of laboratories and campus practice bases to build, expand and transform laboratories. 
In addition, we should also build a part of the practice of extracurricular scientific and technological innovation activities, students' independent open experiment. In recent years, college students' extracurricular scientific and technological innovation activities have been vigorously carried out in colleges and universities around the country, and the activity forms have various kinds of science and technology competitions, such as electronic design competition, embedded system competition, intelligent car race, etc, there are college students' innovative training program, in which students apply for project research and development project etc. These extracurricular activities greatly stimulate the enthusiasm of college students to participate in scientific and technological innovation, cultivate practical ability and innovative ability, and play an important role in training applied talents. In the course of teaching, we should design and develop the rich science and technology innovation activity oriented teaching link, both provide a simple introduction to basic training, it can guide the junior college students to participate in the innovative practice step by step; It can also provide comprehensive resources with large scale and difficulty to meet the needs of students with a certain basis and experience. The latter is more open in the content, including all kinds of system analysis, modeling and design and development, it has certain function of application system, involving technology, comprehensive strength, and it aims to expand the field of vision, cultivating students' ability to innovate, meanwhile it can also join in preparation for all kinds of competition, innovation training program and other activities of students training.

\section{CONCLUSIONS}

Automation combined with " $3+1$ " trainningmode, with regular class and experimental class trainning characteristics, to improve the quality of undergraduate education and teaching efficiency, collaboration between colleges to cultivate innovative talents, build can fully reflect automation features innovative talent trainning scheme. On the basis of taking int account the development trend of subject, professional knowledge is dominated by weak power, which combines strong power with intelligent control and gives consideration to the content of mechanical design. Docking 2025 made in China, facing the pearl river delta and a large bay area of guangdong, radiation guangdong area, closely with the local economy in electrical and electronic equipment manufacturing, intelligent control, system integration, testing, power electronics, electronic information, control, the characteristics of the process integration of multiple disciplines, develop "thick foundation, wide caliber, focus on practice, emphasizes the application" of engineering applied creative talents.

\section{ACKNOWLEDGEMENT}

This research was financially supported by the research on new model of automation professional engineering education (2015GXJK151), Information Full Life Cycle Cultivation of Talents Teaching Team (GDJX2017005), (GDJX2017002),

Wuyi University - Jiangmen Southern Education Equipment Innovation Industry City Practice Base (GDJX2017006).

\section{REFERENCES}

[1] Bi.-L. Gu, "Developing innovative engineering talents," Beijing: Tsinghua Journal of Education, vol. 4, no. 35, pp. 1-6, 2014.

[2] Z.-G. Chen, "Research on training mode of engineering applied innovative talents in Local Universities," Beijing: Research in Higher Education of Engineering, vol. 1, pp. 75-80, 2012.

[3] J. Lin, "Cultivation of excellent engineers - Systematic reform of Engineering Education," Beijing: Tsinghua University Press, pp. 46-58, 2013.

[4] C. Yuxaing and A. Hong, Innovation theory and practice of Higher Engineering Education, Beijing: Science Press, Feb 2015, pp. 230-252.

[5] W. Li, "A brief analysis on the problems and coping strategies of higher engineering education in China," Anhui: The Science Education Article Collects, vol. 02, no. 63, pp. 63-64, 2014.

[6] S. Hui, "Thinking and practice of the education and training activities of Engineering Applied Innovative Talents," Beijing: China Higher Education Research, vol. 09, no. 27, pp. 88-89, 2010.

[7] S. M. Li, "Exploration of innovative talent cultivation model in teaching specialized courses," Education Teaching BBS, vol. 08, pp. 138-139, 2018.

[8] F. F. Shi et al., "Innovative talent training model of local colleges and universities with industry characteristics from the perspective of collaborative innovation," Teaching and Educating People (BBS), vol. 09, pp. 30-32, 2017.
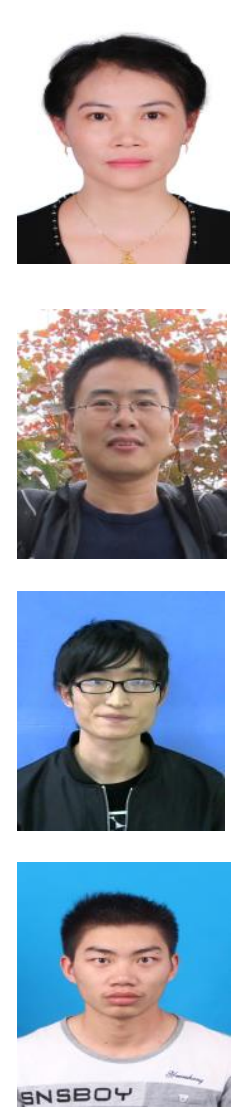

Yingying Fu was born in 1992, Xinyang, Henan, Guangdong province China. He is a M. S. candidate in Wuyi University. His research interests include einformation processing and communication research, image processing.

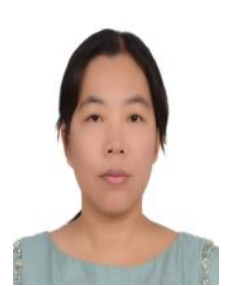

Shufen Liang was born in 1975, Jiangmen Guangdong. She got the master's degree in control theory and control engineering from hebei university of technology. Now, she teaches at Wuyi University. She is the master tutor, deputy director of Equipment Department. Her research interests include pattern recognition, information processing and communication research.

Hongwei Yue received the Ph.D degree in applied mathematics from Guangdong University of Technology, China, in 2013. He is an associate professor in School of Information Engineering, Wuyi University, Jiangmen, China. His research interests include image processing, biomedical instrument, and information security.

Fangchen Yang was born in 1995, jiangxi yichun, China Guangdong province. He got a master's degree in information and communication engineering. His research direction is the image processing field.

Chengfei Li received the M.Sc. and Ph.D. degrees from Beijing University of Chemical Technology in 1999 and 2007, respectively. She is currently an associate professor in the Department of Automation at University of Wuyi. Her research focuses on industry control, intelligence control, vision detection, image processing and data mining. 